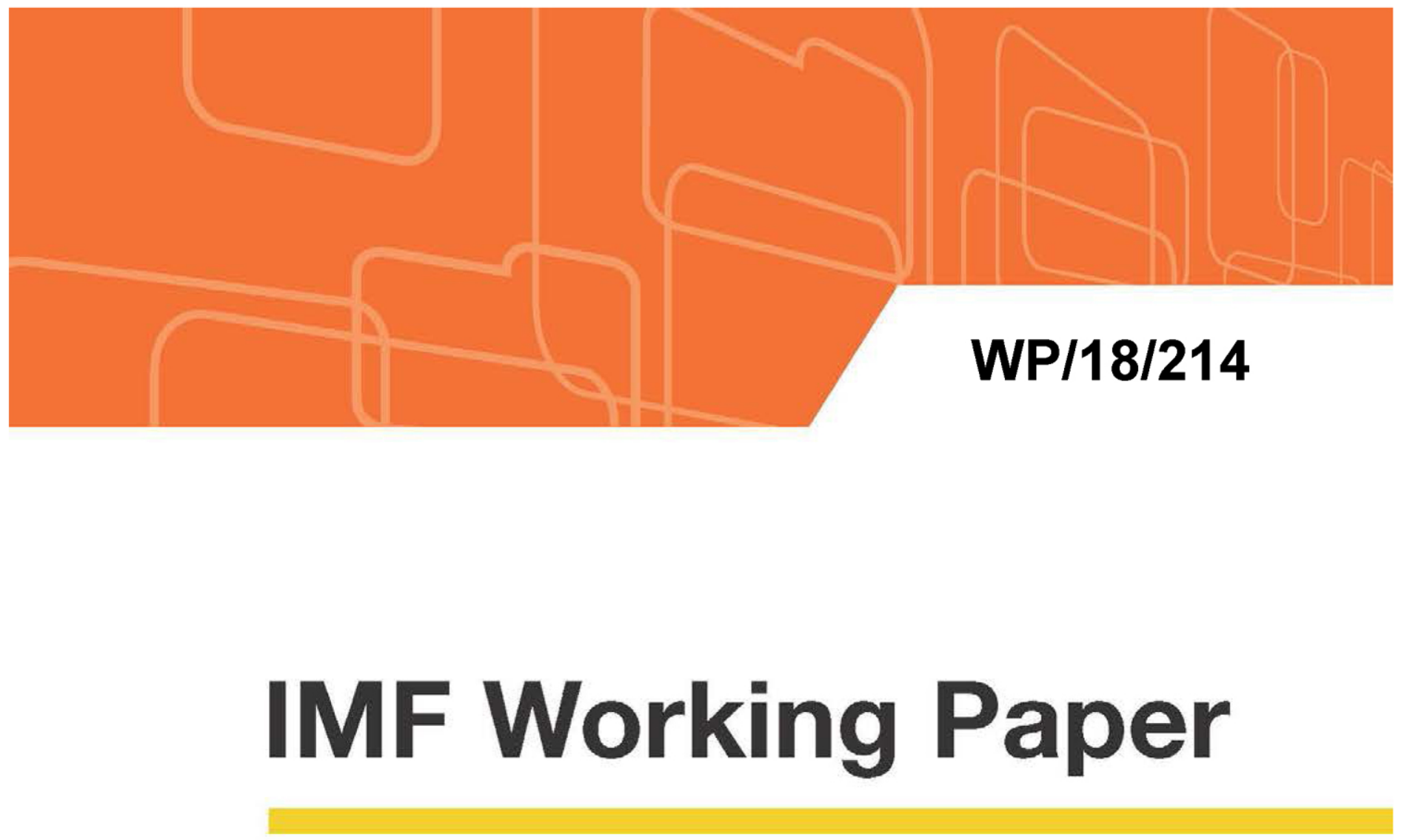

\title{
Revisiting the Determinants of Capital Flows to Emerging Markets-A Survey of the Evolving Literature
}

by Swarnali Ahmed Hannan

IMF Working Papers describe research in progress by the author(s) and are published to elicit comments and to encourage debate. The views expressed in IMF Working Papers are those of the author(s) and do not necessarily represent the views of the IMF, its Executive Board, or IMF management.

$$
\text { I N T E R N A T I O N A L M O N E T A R Y F U N D }
$$




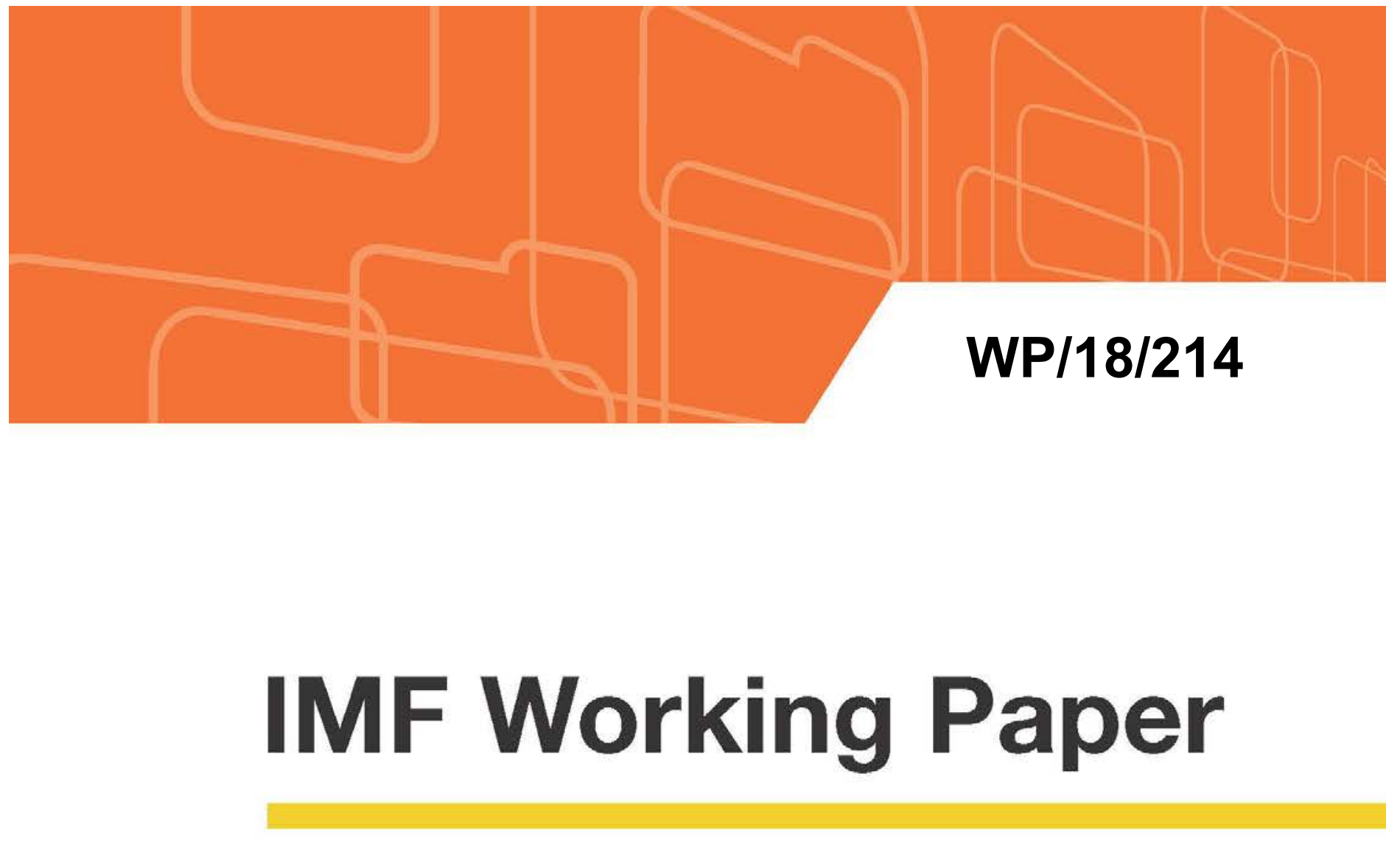

\section{Revisiting the Determinants of Capital Flows to Emerging Markets-A Survey of the Evolving Literature}

by Swarnali Ahmed Hannan

IMF Working Papers describe research in progress by the author(s) and are published to elicit comments and to encourage debate. The views expressed in IMF Working Papers are those of the author(s) and do not necessarily represent the views of the IMF, its Executive Board, or IMF management.

$$
\text { I N T ER N A T I O N A L M O NETAR Y FU N D }
$$




\title{
IMF Working Paper
}

Research Department

\section{Revisiting the Determinants of Capital Flows to Emerging Markets-A Survey of the Evolving Literature}

\section{Prepared by Swarnali Ahmed Hannan ${ }^{1}$}

Authorized for distribution by Luis Cubeddu

September 2018

\section{IMF Working Papers describe research in progress by the author(s) and are published to elicit comments and to encourage debate. The views expressed in IMF Working Papers are those of the author(s) and do not necessarily represent the views of the IMF, its Executive Board, or IMF management.}

\begin{abstract}
This paper documents the evolution of gross and net capital flows to emerging market economies and surveys the large literature on the potential drivers. While the capital flow landscape has been shaped by the evolution of both global and country-specific factors, the relative importance of these factors has varied over time and differs depending on the type of capital flows. The findings from the survey of the literature thus underscore the importance of policies in both source and recipient countries in shaping capital flows.
\end{abstract}

JEL Classification Numbers: F3, F21

Keywords: Capital flows, emerging markets, push and pull factors, literature survey Author's E-Mail Address: sahmed@imf.org

\footnotetext{
${ }^{1}$ The author is grateful to Luis Cubeddu, Robin Koepke, Nicolas E. Magud, Cameron McLaughlin, Jonathan D. Ostry, and Francisco Rivera-Batiz for helpful comments and discussions. This paper will be a chapter in Francisco L. Rivera-Batiz, ed., Encyclopedia of International Economics and Global Trade, Vol. 3: International Money and Finance, World Scientific Publishing Co., Singapore, Chapter 5, forthcoming 2018.
} 


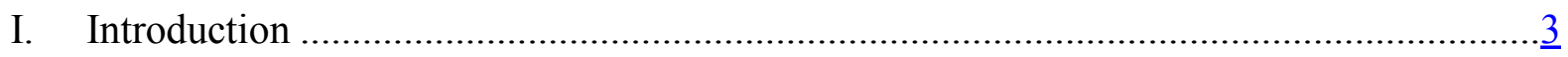

II. Evolution of Capital Flows to Emerging Markets and Developing Economies ................ 4

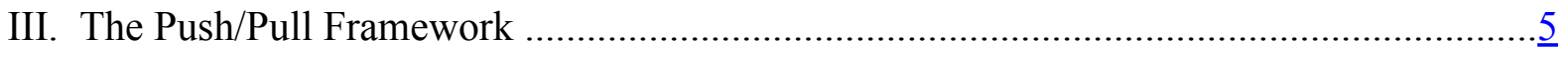

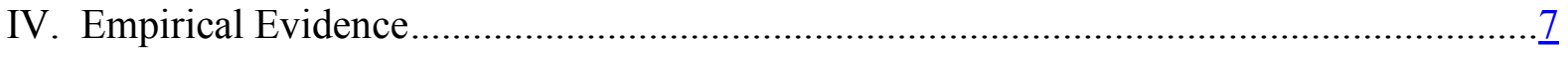

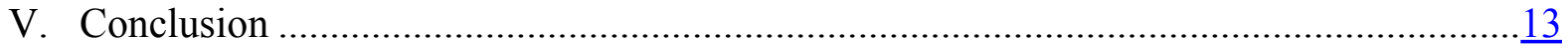

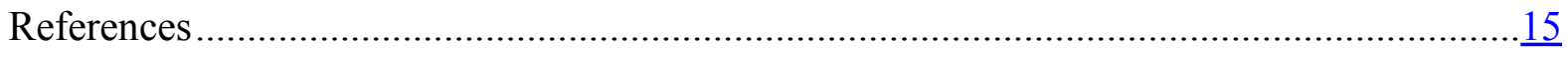

Figures

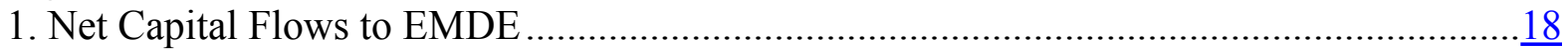

2. Net Capital Flows to EMDE and AM (Share of GDP) ................................................ $\frac{18}{19}$

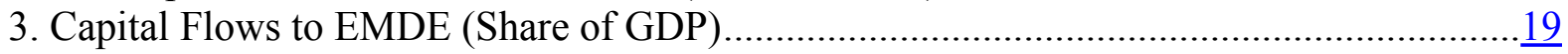

4. Net Capital Flows to EMDE (Share of GDP) ................................................................

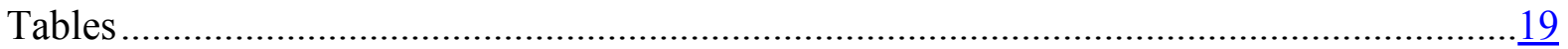

1. Stylized Overview of the Theoretical Benefits of Net and Gross Capital Flows ................ $\underline{20}$

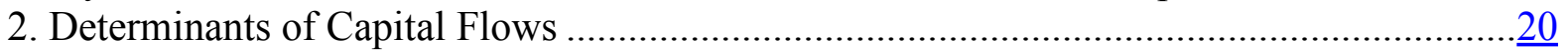




\section{INTRODUCTION}

Early flows of foreign capital to emerging economies date back to the pre-World War I era when Britain invested in infrastructure and railways in Argentina, India, and other countries, that were known as emerging markets. In fact, a World Bank report identifies at least four major surges in private capital flows during the period of 1870 to $2000 .{ }^{i}$ These episodes of rapid capital flows are usually a part of a broader, periodic process of rapid expansion of the global economy, typically during times of rapid diffusion of technology, strong growth, and expanding trade.

The modern-day literature on capital flows emerged in the early 1970s when international bank lending to developing countries rose rapidly owing partly to the oil price shock. The early part of the next decade witnessed a sharp drop in flows following the Latin American debt crisis. However, against the backdrop of recession in the US as well as improvements in fundamentals in a lot of recipient countries, flows rebounded to Latin America in the late 80 s and early 90s. The flows had an upward trend again until the Asian Financial crisis hit in the late 90s, when there was a sudden decline for several years. But this was followed by resurgence in the 2000s, until the Global Financial crisis (GFC) erupted in 2008. Though there was a sharp pick up following the downturn during GFC, capital flows slowed down from 2011 until 2016, and then picked up in 2017.

The rebound of the capital flows to Latin America in the 1990s, following the Latin American debt crisis, provided the seed for the question that still intrigues the literature in this field: are flows driven by external or domestic factors? Was the recession in the US what prompted investment in Latin America or was it the improvement of domestic fundamentals in these economies? Starting from that vantage point, the literature has focused on how the evolving global conditions and country specific factors have contributed towards explaining the evolution of capital flows over time. The determinants of capital flows to emerging markets are thus divided into what is known as "push" and "pull" factors. The push factors are external conditions (or supply-side factors) that underpin the supply of global liquidity, and include variables like global risk aversion, global commodity prices, US economic growth, and U.S. interest rates. On the other hand, pull factors are the domestic characteristics (or demand-side factors) that influence risks and returns to investors, and include domestic macroeconomic fundamentals, domestic policies, market imperfections, and domestic cyclical components like the economic growth and the interest rate in the country.

The conventional wisdom was that domestic factors were mostly responsible for the surge of capital inflows in the 1990s (Mejia 1999, IMF 1993). But Calvo et. al (1993) provide evidence that though fundamental and political reforms matter, global factors like the drop in U.S. short-term interest rates, the recession in the U.S., the sharp swings in the private capital account of the U.S. balance of payments, and the changes of regulation in international capital markets were the predominant drivers of capital flows in Latin American countries. The subsequent literature focused on either supporting the authors' claim (Fernandez-Arias 1996) or refuting the argument (Chuhan et. al 1998). 
The debate on the relative importance of push versus pull factors continued into the 2000s but within the different context of the evolving global macroeconomic developments. With the availability of more granular data, literature moved on to focus on the determinants of specific components of capital flows. With the advent of the global financial crisis, the capital flow landscape changed remarkably. Still maintaining the push-pull framework, many papers focused on understanding the capital flow slowdown (IMF 2016b) and how unconventional monetary policies have influenced flows (Ahmed and Zlate 2014).

An understanding of the relative importance of push versus pull factors has important consequences for policy making. The findings of the survey suggest that, while the relative importance can vary over time and can be subject to academic debate, both push and pull factors determine the evolution of capital flows. Hence, policies in both source and recipient countries are important in driving capital flows to emerging markets.

The rest of the paper is organized as follows. Section II documents the evolution of capital flows to emerging markets and developing economies, describing net, gross and composition of flows. Section III explains the push/pull framework, the main model used to understand the drivers of capital flows. Section IV surveys the vast literature on the determinants of capital flows. Section V concludes.

\section{Evolution of CAPital Flows to Emerging Markets AND DEVELOPING ECONOMIES}

The modern history of capital flows to emerging markets is characterized by an uneven process of successive waves of investment, each of which was followed by financial or political crisis (Global Development Finance 2000). The upswings and downswings witnessed in the data closely matches events like the Latin American debt crisis, the Asian financial crisis and, more recently, the global financial crisis. Net capital flows to Emerging Markets and Developing Economies (EMDEs) rose strikingly from less than 1 percent of Gross Domestic Product (GDP) in early 1980s to more than 4 percent of GDP around mid1990s (Figure 1). ${ }^{\text {ii }}$ The net capital flows to EMDEs slowed from 2011 until 2016, but then picked up in 2017 (the last year covered in the survey). In dollar terms, this translated to a whooping rise of net capital flows from less than 100 billion U.S. dollars in early 1980s to a peak of 719 billion U.S. dollars in 2010. Higher frequency data (until August 2018) from EPFR (Equity Portfolio Fund Research) suggest that flows to EMDEs have slowed down from around the second quarter of the year.

The capital flow environment witnessed significant changes since the 1980s, both in terms of the type of flows (gross inflows versus gross outflows) and in the categories of flows. ${ }^{\text {iii }}$ Net capital flows to EMDEs, as a share of GDP, have been historically higher than for advanced market economies (Figure 2) since net flows in advanced market economies (AMs) are influenced by both gross inflows and gross outflows, while those facing EMDEs are influenced by gross inflows predominantly (Pagliari and Hannan 2017). Until early 2000, net capital flows in EMDEs were driven by gross inflows with gross outflows almost flat. 
However, gross outflows rose gradually since then, remaining almost flat in 2011-2017 (Figure 3), and were increasingly important for the dynamics of net capital inflows (IMF 2016b).

The composition of net capital flows to EMDEs changed over the decades. ${ }^{\text {iv }}$ The dramatic rise of foreign direct investment flows, especially in the 1980s and 1990s, stood out (Figure 4). While other investment flows constituted the highest share in the 1980s, by 1995, foreign direct investment flows constituted the highest share amongst all capital flows. Compared to foreign direct investment, other investment flows and portfolio flows exhibited more volatility and swings, with gross inflows in portfolio and other investments around two and four times more volatile than foreign direct investment, respectively (Pagliari and Hannan, 2017). In particular, net other investment flows-reflecting partly developments during the Latin America debt crisis - rose sharply in early 1980 but then fell gradually until 1990. Notwithstanding some occasional upswings, net other investment flows displayed a downward trend until around the late 1990s. On the other hand, net portfolio investment flows continued to rise until the mid-1990s and then faced a downward trend until early 2000. One caveat when discussing the composition of flows is that, with increased complexity of the nature of flows, mismeasurement could occur when categorizing them and one category of flow could be mislabeled as another type. This adds further challenges to policy making.

\section{The Push/Pull framework}

The theoretical rationale for cross border flows of capital is based on the premise that these flows raise economic welfare on the production side-via more efficient allocation of capital-and on the consumption side-via consumption-smoothing and therefore an improved consumption path for the providers and recipients of capital flows (Koepke 2015). However, as summarized in Table 1, there are some key differences between the benefits from gross capital flows compared to net capital flows. Net capital flows, the flipside of the current account balance ${ }^{\mathrm{v}}$, are typically regarded as exchanges of assets in return for goods and services (Obstfeld and Rogoff, 1995) and thus studied using an intertemporal framework. For example, from the consumption side, net capital flows would indicate that agents are trading present consumption against future consumption. On the other hand, gross capital flows are viewed as trade in assets for other assets and thus regarded as intratemporal trade which helps countries to share risks internationally by diversifying their portfolio (Grubel 1968).

The literature usually divides the determinants of capital flows to emerging markets into external "push" factors and domestic "pull" factors (Table 2). The underlying idea behind this approach is that of the portfolio balance approach, in which expected returns, risk, and risk preferences across countries matter in determining capital flows (Ahmed and Zlate 2014; Hannan 2017). The distinction between the push and the pull factors was popularized by Calvo et. al (1993) and Fernandez-Arias (1996), and continues to provide the theoretical framework for the empirical work since the 1990s. An alternative way to model capital flows 
is by using the international capital asset pricing model of Bohn and Tesar (1996) but this approach is less used in literature than the push-pull framework.

The push factors are external conditions (or supply-side factors) that underpin the supply of global liquidity and lure investors to increase exposure to EMDEs. The idea of push factors is based on the neoclassical theory, which predicts that capital reacts to interest rate differentials between countries and flows from countries with low return to those with high return. Typically, the push factors include variables like global risk aversion, global commodity prices, U.S. (or a group of advanced economies) economic growth, and U.S. (or a group of advanced economies) interest rates. More recent literature also includes factors like global liquidity, U.S. corporate spreads, and the U.S. yield gap (IMF 2016b). In particular, there is a large body of work looking at the impact of global commodity prices on capital flows which also touches on the connection between the commodity price super-cycle and the ebb and flow of financial capital (see Reinhart et al. (2016) and the references therein).

On the other hand, pull factors are the domestic characteristics (or demand-side factors) that influence risks and returns to investors, and depend on local macroeconomic fundamentals, official policies, and market imperfections (Ghosh et. al 2014, Fernandez-Arias and Montiel 1996). In some cases, the pull factors are further divided into cyclical and structural factors. ${ }^{\text {vi }}$ The cyclical factors include country-specific time varying factors like economic growth performance and the interest rate. The country-specific structural factors include slow moving variables that represent specific characteristics or features of the economy that attract foreign investors to a particular country, including, inter alia, variables like trade openness, foreign reserves, exchange rate regime, institutional quality, income per capita, capital openness and financial development.

Using this framework, the starting point of empirical regression analysis is thus a general empirical model as used by Hannan (2017):

$y_{i, t}=\alpha_{0}+\sum_{i=1}^{n-1} \alpha_{i} D_{i}+\beta_{0}$ External $_{t}+\beta_{1}$ Domestic $_{i, t}+\varepsilon_{i, t}$

The left hand-side, $y_{i, t}$, represents the ratio of flows - either total or key componentsto country $i$ during time period $t$, as a fraction of the country's nominal GDP. The flows as a share of GDP are modeled as a function of fixed effects $\left(D_{i}=1\right.$ if an observation pertains to country $i, 0$ otherwise), External, which is a vector of variables representing external conditions or push factors, and Domestic, a vector of variables representing domestic or pull factors. There are some variables that are represented as the relative differential between global versus domestic counterparts, and thus can be regarded as a combination of push and pull factors. This group includes variables like the growth differential vis-à-vis the U.S. (or a group of advanced economies) and the interest rate differential vis-à-vis the U.S. (or a group of advanced economies)

Beyond running statistical regressions using the entire sample, it is a common practice in the literature to focus on episodes with extreme capital flow movements, also known as 
surges (sudden rapid inflow of capital flows) and sudden stops (sudden rapid decline of capital flows). The motivation of this exercise is well presented in Ghosh et. al (2014). The authors point out that large capital flows are not just scaled-up normal flows, but can behave in a different manner qualitatively compared to normal flows. When analyzing the determinants of extreme capital flow episodes, the literature usually identifies the episodes using some criteria, by restricting the sample to some standard deviation above or below mean or using certain percentile of the distribution.

\section{EMPIRICAL EVIDENCE}

The literature on the determinants of capital flows in emerging markets has evolved in line with the economic developments in these countries taking into consideration the broader global scenario as the backdrop. As noted earlier, one of the common themes underlying the debate throughout the years has been the relative importance of push versus pull factors. An understanding of the relative importance of push versus pull factors has important consequences for policy making. If the causes are exogenous for the emerging market, then compensatory policies are appropriate while if the causes are predominantly domestic, then direct policy design is more appropriate and effective (Taylor and Sarno, 1997).

\section{What Explains the Capital Inflow Surges of the 1990s?}

The support for pull factors...

Early literature attributed the rapid inflows to emerging markets in the 1990s to domestic factors. In particular, as explained in Lopez-Mejia (1999), the main reasons for investor interest in emerging markets were the search for higher yields and risk diversification. The perception of higher risk-adjusted returns increased due to, inter alia, two domestic factors:

(i) creditworthiness improved in a lot of emerging markets due to external debt restructuring, (ii) the productivity gains owing to structural reforms pursued.

An IMF (1993) review of capital inflow surges in six countries-Chile, Colombia, Egypt, Mexico, Spain, and Thailand-concluded that domestic factors were the most important for these episodes. While foreign interest rates and growth mattered, they were not the dominant causes. The authors provide two key arguments for this conclusion: (i) the timing of the surges did not coincide with the timing of the changes in the external factors, (ii) the timing, persistence and intensity of the surges varied across the countries reviewed. However, the authors show that the rapid inflows can be attributed to different domestic factors ranging from real economy policy changes to tightening of domestic credit market conditions. For example, in Thailand, the surge can be attributed to fiscal and structural policy changes with broadly unchanged credit policies. On the other hand, the tightening of credit conditions was a major underlying reason in Colombia and Egypt with fiscal and structural policy changes helping as well. 
$\ldots$ and the resistance from push factors

When the conventional wisdom was that domestic factors were mostly responsible for capital inflows, the seminal work by Calvo et. al (1993) tilted the scale heavily towards the predominance of external factors. The authors start off with a simple observation that, contrary to the popular notion, capital was returning to most Latin American countries despite striking differences in macroeconomic policies and economic performance across countries. Though fundamental economic and political reforms - including the restructuring of external debt - mattered, domestic policies alone could not be the prime driver given the divergence amongst the countries.

One of the underlying themes thus responsible for the rapid inflows is the external shock common to the region. While there could be many external factors responsible for this, there are four key ones: (i) the sharp drop in U.S. short-term interest rates. This improved the solvency of the Latin American debtors by decreasing the external debt service on floatingrate obligations; (ii) the prolonged recession in the U.S. and other advanced economies and the decline in Latin America's terms of trade throughout the previous decade, which contributed towards the widening of Latin America's current account deficit, which then needed to be financed by inflows of capital; (iii) data supported the notion that the swings in capital outflows from the U.S. acted as an external catalyst that influenced the size of capital inflows into Latin America. In other words, the origin was the sharp swings in the private capital account of the U.S. balance of payments; (iv) there were important regulatory changes that decreased transaction costs related to international capital markets. The authors used monthly data for ten Latin American countries spanning the period January 1988 to December 1991 to substantiate these claims.

\section{The debate continues}

Since Calvo et. al (1993), the subsequent literature focused on either supporting the authors' claims-via more improved econometric techniques-or refuting the argument via challenging the data, methodology, and providing further evidence in support of the importance of domestic factors.

There were two key studies in favor of the relative importance of the external factors. Firstly, Fernandez-Arias (1996) study the determinants and sustainability of the widespread private capital inflows to middle-income countries after 1989. The paper addresses the pull/push issue by constructing a structural model of international capital allocation where country creditworthiness is analyzed. The paper concludes that the "pull" story is based on the flawed assumption that country creditworthiness is a function of domestic factors. The paper shows, both theoretically and empirically, that external factors have a non-negligible impact on a country's creditworthiness - a channel through which the recipient economies are exposed to external shocks but is widely ignored in literature. Overall, the paper concludes that, with the exception of a few countries (e.g. Mexico), external factors are the most important in explaining the surge of capital inflows during the period studied. 
Secondly, Taylor and Sarno (1997), using cointegration techniques, study the determinants of the large portfolio flows from the U.S. to Latin American and Asian countries during 1988-92. The paper provides evidence that global and country-specific factors are equally important in determining the long-run movement of equity flows for Asian and Latin American countries. However, global factors are much more important than domestic factors in explaining bond flows. In particular, U.S. interest rates constitute the most important determinant of the short-run dynamics of portfolio, especially bond, flows to developing countries.

On the other hand, there were a few studies that went against the finding of Calvo et. al (1993) and continued to emphasize the relative importance of pull factors. For instance, Chuhan, Claessens and Mamingi (1998) use monthly US capital flows to nine Latin American and nine Asian countries in a panel data approach to explore similar questions to those of Calvo et. al (1993), but derive different conclusions. While the external factors-particularly the decline in U.S. interest rates and the slowdown in U.S. industrial production-are important in explaining capital inflows, country-specific factors are also at least equally important, particularly for Asia. Equity flows are more sensitive than bond flows to global factors, while bond flows are more sensitive to a country's credit rating and secondary market debt price. The paper differs from Calvo et. al (1993) in including a number of additional explanatory variables and a different econometric methodology. The most important difference relates to the data used for capital flows. Due to the unavailability of monthly capital flow data, Calvo et. al (1993) had used monthly international reserves as proxies for capital flows. The authors, claiming that official reserves accumulation and capital inflows are not necessarily identical, particularly when private capital inflows are substantial, investigated directly the behavior of capital inflows by employing monthly data on capital flows. The paper used monthly U.S. capital flow data on gross and net purchases of non-US long-term securities for January 1988 through September 1992. The data were sourced from the US Treasury's International Capital Reports (TIC).

Finally, two additional studies, World Bank (1997) and Ghosh and Ostry (1993) also find evidence that domestic factors matter more than external factors. In particular, the World Bank paper shows that structural factors were behind the rapid rise of capital inflows to emerging markets.

\section{The Early 2000 to Pre-crisis Era}

The debate on the relative importance of push versus pull factors continued in the 2000s but against a different context in line with the evolving global macroeconomic developments. With the availability of more granular data, literature moved on to focus on the determinants of specific components of capital flows.

Albuquerque et. al (2005) study the relevance of global factors as determinants of FDI flows. The motivation of the focus on FDI flows was the rapid increase in foreign direct investment to emerging markets in the previous two and a half decades or so. The paper, using 
a large panel data set comprising industrial and developing countries, provides evidence that the rapid increase in FDI flows could be attributed to an increasing role of global factors due to the increased integration of world capital markets following the reforms and liberalization efforts of the mid-1980s and 1990s. The paper also finds that domestic factors like local productivity growth, trade openness, financial depth, low government burden, and macroeconomic stability were important drivers. However, local factors were becoming less important over time in accounting for the variation in foreign direct investment. This did not mean that domestic policies were less relevant since domestic factors still accounted for a sizeable amount of variation in foreign direct investment.

Apart from Albuquerque et. al (2005), there were a few other studies that concentrated on specific components of capital flows, summarized in Koepke (2015). For example, Baek (2006) finds that push factors are more important for portfolio flows to Emerging Asia than to Latin America. De Vita and Kyaw (2008) show that productivity growth in emerging markets is more important for FDI flows than portfolio flows, but domestic money supply growth is the predominant driver of portfolio flows.

\section{Along Came the Global Financial Crisis (GFC)}

The capital flow landscape has changed remarkably since the global financial crisis (GFC). While the pre-crisis era was marked by a gradual (and, sometimes, a rapid) rise in capital flows owing to financial integration and strong growth prospects in the emerging markets, capital flows dropped sharply following the crisis (Hannan 2017). There was a brief surge post-GFC, but flows have been subject to great volatility since then.

The literature since GFC continued to understand the relative importance of push versus pull factors, but many of the key papers concentrated on the slowdown in capital flows and the evolving capital flow landscape following the crisis. With the availability of more detailed data, some literature continued to focus on the differences in the determinants of the various components of capital flows, and highlighted that the determinants hinge upon whether the flow considered is net, gross inflow or gross outflows. One of the recent focus of the literature has been to explain the capital flow slowdown witnessed in data between 20112016. In a chapter titled "Understanding the slowdown in capital flows to emerging markets", IMF (2016b) found that both weaker inflows and stronger outflows contributed to the slowdown, and could be explained by the narrowing differential in growth prospects between emerging markets and advanced economies.

Broadly speaking, the literature post-GFC crisis focused on three aspects: 1) understanding the determinants of capital flows during and following the GFC, 2) continuing the traditional debate on the role of push versus pull factors, but adding more nuances by investigating the circumstances and context when one factor dominates over other, 3) bringing out the new features of the capital flow landscape, particularly post-GFC.

The determinants of capital flows during and following GFC 
Fratzscher (2012) analyze the causes of the 2008 collapse and the subsequent surge in global capital flows. The paper uses a novel data set, compiled by EPFR, which contains daily, weekly and monthly flows by more than 16,000 equity funds and more than 8000 bond funds. Econometrically, the paper adopts a factor model using a novel high frequency portfoliocapital dataset comprising 50 economies. Unsurprisingly, the paper finds that the key crisis events and global liquidity and risk profiles are the main determinants for the developments in capital flow episodes during the crisis and the subsequent recovery. However, the effects are highly heterogeneous across countries, with the heterogeneity depending upon domestic factors like quality of domestic institutions, country risk and the strength of domestic macroeconomic fundamentals. Overall, the push factors were the main drivers of capital flows during the crisis, while pull factors were the dominant factors for the dynamics during 2009 and 2010 .

Similar conclusions are obtained by IMF (2014). The research in this report seeks to explain the capital flow events following what is known as the taper tantrum episode- the sharp reaction of markets, in terms of significant outflows across a large group of emerging markets, during the summer of 2013 when the Fed discussed the prospects for gradually unwinding its unconventional monetary policy. The paper finds that asset prices and capital flows were indiscriminately hit across countries during the initial periods following the Fed's announcement, but over time there was greater differentiation depending on the domestic characteristics of emerging markets.

Push versus pull — the more nuanced debate

Ghosh et. al (2014) examine in detail why and when capital sometimes surges to emerging markets using data of net capital flows for 56 emerging markets in the period of 1980-2011. The key finding of the paper is that global factors like that U.S. interest rates and global risk aversion act as, what the authors call, "gatekeepers" that determine the timing of capital flow surges to emerging markets. However, whether a particular country receives a surge, along with the magnitude of that surge, depends on domestic country factors like external financing need, capital account openness, and the exchange rate regime.

Ghosh et. al (2016), using a sample of 53 emerging markets over 1980-2014, explore whether countries with open capital accounts are dependent upon global events or can take policy actions during inflow surges to mitigate the negative effects of flow reversals. While global conditions play an important role on crisis susceptibility, domestic policies also mattercountries with more macroeconomic and financial vulnerabilities during boom times and significant debt flows are more likely to see inflow surge episodes ending in a financial crisis.

The new features of the capital flow landscape

Forbes and Warnock (2012) show that the determinants of gross capital flows, be it gross inflows or gross outflows, can be considerably different from those of net flows, upon which the previous literature focused on. The paper develops a new methodology to identify episodes of extreme capital flow movements. The authors find that global factors, especially 
global risk, are significantly associated with sudden stop (sharp decrease in gross inflows) and retrenchment (sharp decrease of gross outflows) episodes. Domestic factors are less important, with little association between capital controls and the probability of having surges or stops driven by foreign capital flows. The authors find evidence that contagion, via trade, banking or geography, is associated with stop and retrenchment episodes.

More recently, Ahmed and Zlate (2014) have explored the determinants of net private capital inflows to emerging market economies since 2002. While Fratzscher (2012) and the literature following GFC attempted to understand the determinants of capital flows during and following GFC, this paper makes an important contribution to the literature by providing a better understanding of how the features of capital flows have changed since GFC, including how capital flows reacted to the unconventional monetary policy pursued by the Fed. The paper finds that growth and interest rate differentials between emerging markets and advanced economies and global risk aversion are important determinants of net private capital inflows to emerging markets. More importantly, the paper finds that there have been significant changes in the behavior of net capital inflows, particularly for portfolio net inflows, from before the GFC to the period following the GFC. This is partly explained by the greater sensitivity of such flows to interest rate differentials. The unconventional monetary policy of the U.S. is found to have positive effects on total capital inflows as well as portfolio inflows in particular, with the effects larger for portfolio flows and gross inflows.

\section{Criticisms}

One of the attractive features of the push-pull framework is that it is simple and intuitive, yet extremely useful in explaining capital flow movements. However, like any other framework, the push-pull approach has also received some criticism, well analyzed in Koepke (2015). Early criticism focused on the fact that some of the responses of international investors to local market developments do not fall into either external or domestic factors, but may arise through an interaction of country-specific and global developments. There now exists an extensive literature that explores different dimensions of contagion effect (Forbes and Rigobon 2001, Forbes and Warnock 2012). A related issue is that some of the domestic variables can be influenced by global developments and the framework does not strip out the global component from the domestic variables. For example, Fernandez-Arias (1996) finds a positive effect of low U.S. interest rate on the creditworthiness of borrowers to emerging market economies, but this could lead to potential endogeneity issues that are not captured by the push-pull framework.

Another drawback arises from the treatment of factors like growth and interest rate differentials via-a-vis the U.S. (or a set of advanced economies). The academic literature usually uses the growth and interest differentials to explain capital flows by assuming that an increase of growth or the interest rate in the U.S. would have the same impact as a decline of growth or the interest rate of the recipient country. This theoretical idea has not been completely validated, with some evidence showing that the impact could be different (Gupta and Ratha 2000). 


\section{The role of capital controls}

An extensive strand of literature on capital flows has looked in depth the role of policies in shaping flows (see Ostry et. al 2015 and Ghosh et. al 2017 for a detailed exposition). In the spirit of liberalization and globalization, many emerging markets had reduced or removed capital controls in the 1980s and 1990s, and this easing of restrictions on capital flows can be attributed as one of the reasons for the surge of cross-border capital flows during that era (Kose and Prasad 2004).

While flows bring important benefits (discussed in the introduction), sudden surgesparticularly the temporary ones - can complicate macroeconomic management and pose financial-stability risks, warranting the use of capital controls. At the same time, capital controls can create significant costs by creating distortions within the domestic economy and resulting in adverse multilateral outcomes (e.g. global imbalances). How emerging market should handle surges in capital flows has been a key focus of policy discussion (see Ostry (2012) for an exposition on the debate). Ostry et. al (2011a) - an influential paper in understanding capital controls - review the arguments on the appropriate management of inflow surges and conclude that "if the economy is operating near potential, if reserves are adequate, if the exchange rate is not undervalued, and if the flows are likely to be transitory, then controls on capital inflows-together with macroeconomic policy adjustment and prudential measures - may usefully form part of the policy toolkit” (pp: 562).

Literature in this strand has also focus on the effectiveness of capital controls. The view is mixed but there seems to be a consensus that there is no one-size fit all, with the impact of controls depending on a host of other factors. Ostry et. al (2010 and 2011b) find a negative association between capital controls that were imposed before the global financial crisis and the output reductions due to the crisis. Edwards (1999), exploring in detail Chile's case of capital controls during 1978-82 and 1991-98, concludes that the effectiveness of Chile's capital controls has been exaggerated. On the other hand, there were significant costs related to the increase in the cost of capital for small and medium-size firms.

Magud et. al (2011) find that the effectiveness of capital controls varies across time, country, and the type of measures used. Similarly, Baba and Kokenyne (2011), investigating the inflow surges in Brazil, Colombia, Korea, and Thailand in the 2000s, conclude that the impact of capital controls depends on the depth of the policy, the level of capital market development, the developments in other policies, and the persistence of the flows.

\section{Conclusion}

Understanding the relative importance between of push versus pull factors of capital flows is critical to determine the policy response. However, as this paper documents, although the relative importance of these factors can be debated, literature finds that both push and pull factors matter. The more recent work shows that while the incidence of capital flow surges depends on external factors, whether a particular emerging market economy receives that 
surge depends on domestic factors, including the extent of financial market liberalization and global financial market integration. Moreover, the drivers of capital flows depend on the type of flows considered, thus the relative importance of push versus pull factor can be contingent on the type of flow considered.

The relative importance of push versus pull factors is likely to continue to be a central theme of the capital flows literature. Future research will likely to continue to have a more nuanced approach, both in terms of the type of flows as well as circumstances that determine whether pull or push factors matter more. In particular, there is a need to better understand the cyclical versus structural factors responsible for capital flows, the impact of external factors on FDI, and its changing nature; and how the capital flows differ for advanced economies compared to emerging markets. 


\section{References}

Ahmed, S., and A. Zlate, 2014, "Capital Flows to Emerging Market Economies: A Brave New World?” Journal of International Money and Finance, Vol. 48, pp. 221-248.

Baba, C., and A. Kokenyne, 2011, "Effectiveness of Capital Controls in Selected Emerging Markets in the 200s," IMF Working Paper No. 11/281 (Washington: International Monetary Fund).

Bohn, H., and LL Tesar, 1996, 'U.S. Equity Investment in Foreign Markets: Portfolio Rebalancing or Return Chasing?” American Economic Review, Vol. 86, No. 2, pp. $77-81$.

Boz, E., L. Cubeddu, and M. Obstfeld, 2017, "Revisiting the paradox of capital", VOX CEPR Policy Portal: https://voxeu.org/article/revisiting-paradox-capital.

Calvo, G.A., L. Leiderman, and C.M. Reinhart, 1993, "Capital Inflows and Real Exchange Rate Appreciation in Latin America: the Role of External Factors," IMF Staff Papers: $108-151$.

Chuhan, P., S. Claessens, and N. Mamingi, 1998, "Equity and Bond Flows to Latin America and Asia: the Role of Global and Country Factors," Journal of Development Economies, 55, 439-63.

Edwards, S., 1999, "How Effective are Capital Controls?" The Journal of Economic Perspectives, Vol. 13, No. 4, pp. 65-84.

Fernandez-Arias, E., 1996, “The New Wave of Private Capital Inflows: Push or Pull?" Journal of Development Economies, Vol. 48, No. 2, pp. 389-418.

Fernandez-Arias, E. and P. Montiel, 1996, "The Surge in Capital Inflows to Developing Countries: An Analytical Overview," World Bank Economic Review, Vol. 10, No. 1, pp. 51-77.

Forbes, K.J., and R. Rigobonm, 2001, "Measuring Contagion: Conceptual and Empirical Issues," in International Financial Contagion, 43-66. Springer US.

Forbes, K.J., and F.E. Warnock, 2012, “Capital Flow Waves: Surges, Stops, Flight, and Retrenchment," Journal of International Economics, Vol. 88, No. 2, pp. 235-51.

Fratzscher, M (2012) "Capital Flows, Push versus Pull Factors and the Global Financial Crisis," Journal of International Economics, Vol. 88, No. 2, pp. 341-56. 
Ghosh, A.R., J. D. Ostry, and M. H. Qureshi, 2017, Taming the Tide of Capital Flows-A Policy Guide, MIT Press.

Ghosh, A.R., and J.D. Ostry, 1993, "Do Capital Flows Reflect Economic Fundamentals in Developing Countries?" IMF Working Paper No. 93/34 (Washington: International Monetary Fund).

Ghosh, A.R., M. S. Qureshi, J. Kim, and J. Zalduendo, 2014, “Surges,” Journal of International Economics, Vol. 92, No. 2, pp. 266-85.

Global Development Finance, 2000, "Private Capital Flows in Historical Perspective.” World Bank, 119-39.

Grubel, H.G., 1968, "Internationally Diversified Portfolios: Welfare Gains and Capital Flows," American Economic Review, Vol. 58, pp. 1299-1314.

Gupta, D.D. and D. Ratha, 2000, "What Factors Appear to Drive Private Capital Flows to Developing Countries? And How Does Official Lending Respond?" World Bank Publications, 2392.

Hannan, S.A., 2017, "The Drivers of Capital Flows in Emerging Markets Post Global Financial Crisis," Journal of International Commerce, Economics and Policy, Vol. 8, No. 2, pp. 1-28.

IMF, 2016a, "Capital Flows - Review of Experience with the Institutional View," IMF Board Paper, (Washington, D.C.: International Monetary Fund).

IMF, 2016b, "Understanding the Slowdown in Capital Flows in Emerging Markets," World Economic Outlook (Washington, D.C.: International Monetary Fund) Chapter 2, April.

IMF, 2014, "Emerging Market Volatility: Lessons from the Taper Tantrum," IMF Staff Discussion Note (Washington, D.C.: International Monetary Fund).

IMF, 1993, "Recent Experiences with Surges in Capital Inflows," Occasional Paper No. 108. (Washington, D.C.: International Monetary Fund).

Koepke, R., 2015, "What Drives Capital Flows to Emerging Markets? A Survey of the Empirical Literature," (Washington, D.C.: Institute of International Finance).

Kose, M.A., and E. Prasad, 2004, "Capital Accounts: Liberalize or Not?” Finance \& Development, September 1, pp. 50-51. 
Magud, N.E., C.M. Reinhart, and K.S. Rogoff, 2011, "Capital Controls: Myth and RealityA Portfolio Balance Approach,” NBER Working Paper No. 16805.

Ostry, J.D., A.R. Ghosh, and MS Qureshi, 2015, Capital Controls, The International Library of Critical Writings in Economics 308, Edward Elgar Publishing.

Ostry, J.D., 2012, “Managing Capital Flows," Asian Development Review, Vol. 29, No. 1, pp. $82-88$.

Ostry, J.D., A.R. Ghosh, M. Chamon, and M.S. Qureshi, 2011a, "Capital Controls: When and Why?” IMF Economic Review, Vol. 59, No. 3, pp. 562-80.

Ostry, J.D., L. Laeven, M. Chamon, M.S. Qureshi, and A. Kokenyne, 2011b, “Managing Capital Inflows: What Tools to Use?" IMF Staff Discussion Note No. 11/06, (Washington: International Monetary Fund).

Ostry, J.D., A.R. Ghosh, K. Habermeier, M. Chamon, M.S. Qureshi, and D. Reinhardt, 2010, "Capital Inflows: The Role of Controls," IMF Staff Position Note No. 10/04, (Washington: International Monetary Fund).

Pagliari, M.S. and S.A. Hannan, 2017, "The Volatility of Capital Flows in Emerging Markets: Measures and Determinants," IMF Working Paper No. 17/41 (Washington: International Monetary Fund).

Prasad, E., R. Rajan, and A. Subramanian, 2007, “The Paradox of Capital,” Finance and Development Magazine, Vol. 44, No. 1.

Reinhart, C.M., V. Reinhart, and C. Trebesch, 2016, “Global Cycles: Capital Flows, Commodities, and Sovereign Default," American Economic Review, Vol. 106, No. 5, pp. 574-80.

Taylor, M.P., and L. Sarno, 1997, "Capital Flows to Developing Countries: Long-and ShortTerm Determinants," The World Bank Economic Review, Vol. 11, No. 3, pp. 451-70.

World Bank, 1997, "Private Capital Flows to Developing Countries: the Road to Financial Integration,” World Bank Policy Research Report (Oxford: Oxford University Press). 


\section{Figures}

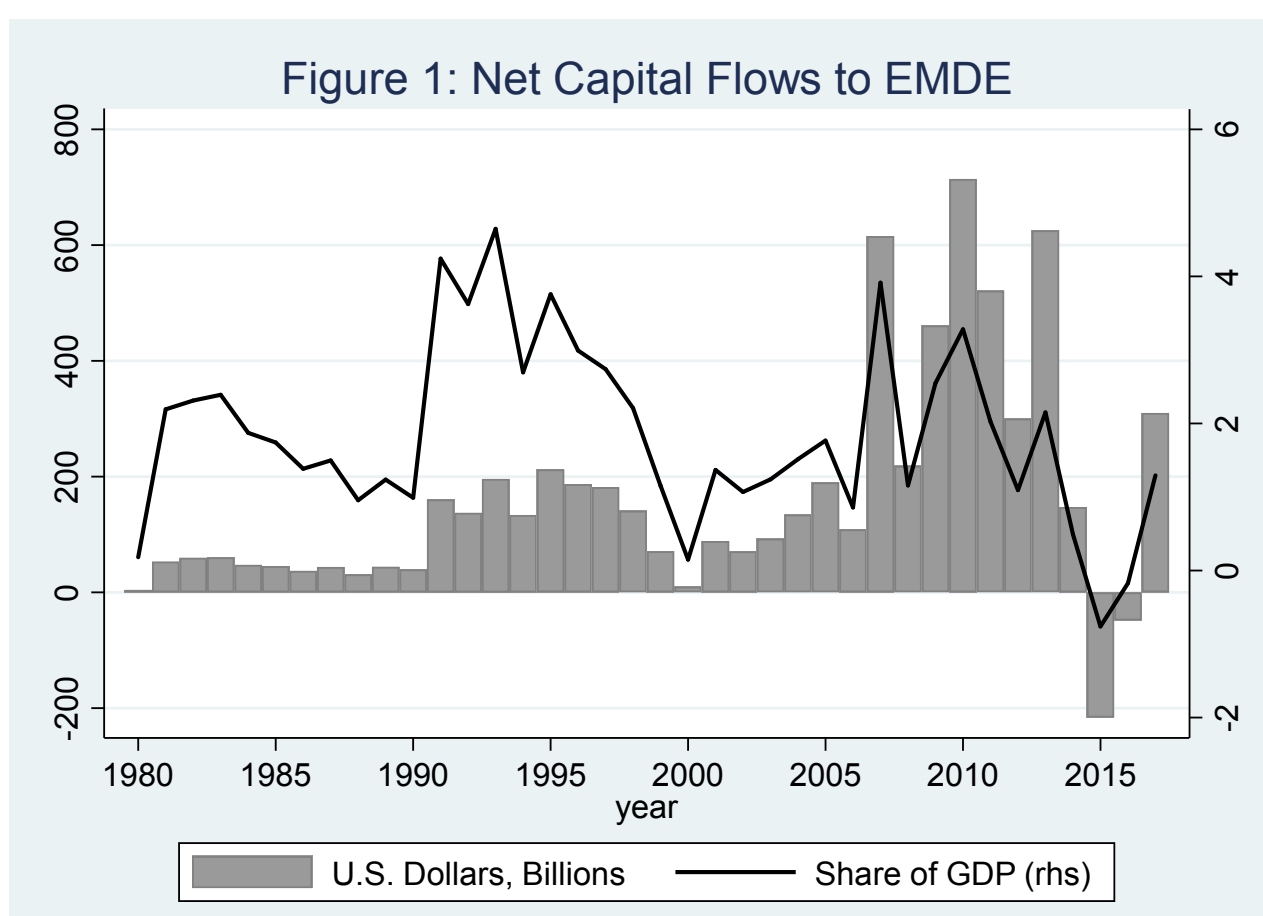

Figure 2: Net Capital Flows to EMDE and AM (Share of GDP)

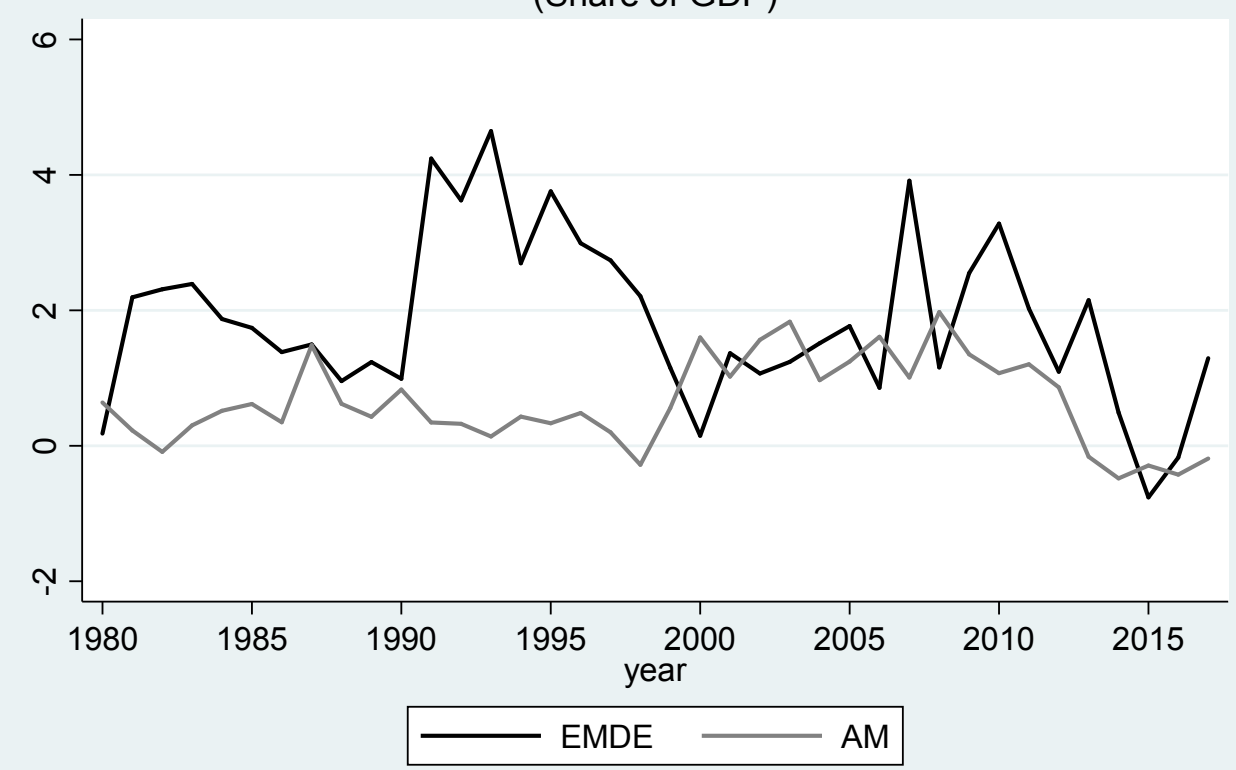


Figure 3: Capital Flows to EMDE (Share of GDP)

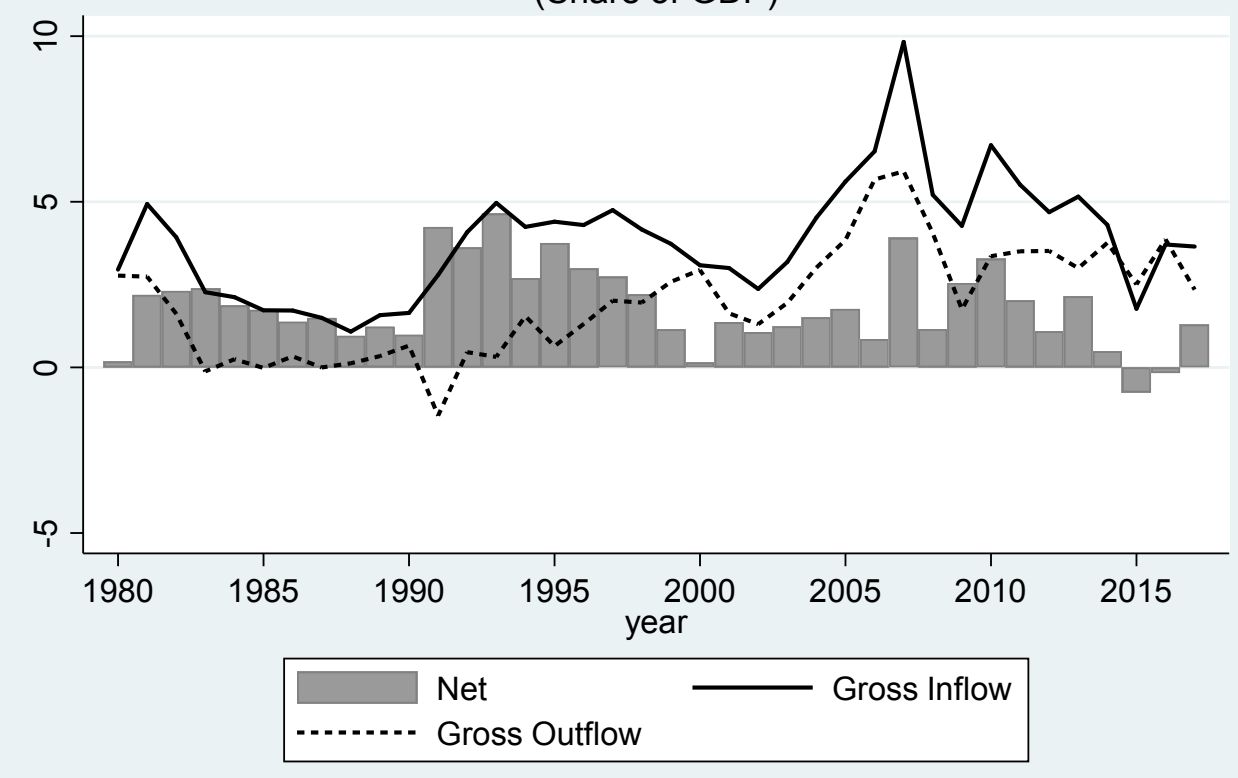

Figure 4: Net Capital Flows to EMDE (Share of GDP)

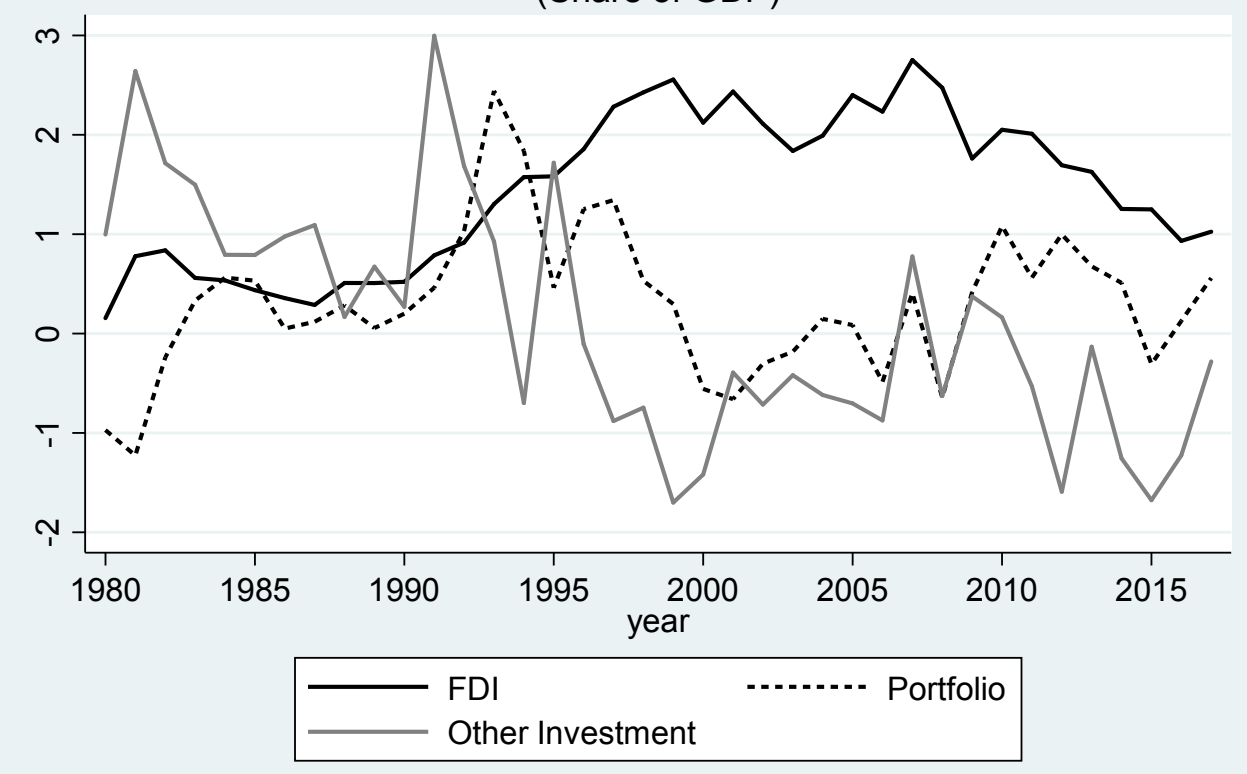




\section{Tables}

Table 1: Stylized Overview of the Theoretical Benefits of Net and Gross Capital Flows

\begin{tabular}{|c|c|c|}
\hline Net Flows & $\begin{array}{c}\text { Production Benefits } \\
\text { capital (higher returns for given amount } \\
\text { of risk) }\end{array}$ & $\begin{array}{c}\text { Consumption Benefits } \\
\text { Improved itertemporal consumption } \\
\text { path (smoothing known/expected } \\
\text { variations in income and returns) }\end{array}$ \\
\hline Gross Flows & $\begin{array}{c}\text { Riskier, but more productive allocation } \\
\text { of global capital (higher return and } \\
\text { more risk that is better diversified) }\end{array}$ & $\begin{array}{c}\text { Reduced state-dependent variability of } \\
\text { income (smoothing unknown/random } \\
\text { variations in income and returns) }\end{array}$ \\
\hline
\end{tabular}

Source: Figure 3 (Koepke 2015)

Table 2: Determinants of Capital Flows

\begin{tabular}{|c|c|c|}
\hline Push/Pull & Push & Structural \\
\hline \multirow{3}{*}{$\begin{array}{c}\text { Growth differential vis-à-vis US } \\
\text { Rate differential vis-à-vis US }\end{array}$} & Global risk aversion & Trade Openness \\
& Commodity prices & FX Reserves \\
& Global liquidity & Exchange rate regime \\
& US Corporate Spread & Institutional quality \\
& US Yield Gap & Income per capita \\
& & Capital openness \\
& & Financial development \\
\hline
\end{tabular}

Source: Table 1 (Hannan 2017)

${ }^{\text {i }}$ Global Development Finance (2000).

${ }^{i i}$ Consistent with the Financial Flows Analytics (FFA) database, net capital flows are always shown as net inflows, defined as gross inflows (change in domestic resident liabilities to foreigners) minus gross outflows (change in foreign assets owned by domestic residents).

iii Contrary to basic economic theory that capital should flows from wealthy countries to poorer countries where returns to capital is higher, a puzzle in literature is that, despite financial globalization of EMDEs, the general 
trend is that of capital flowing from poor to richer countries - also known as the "uphill flow" or the "paradox of capital". For an exposition on this literature, please see Prasad et. al (2007) and Boz et. al (2017).

iv The paper looks at three main categories of capital flows: foreign direct investment (assets and liabilities between resident direct investors and their direct foreign investors), portfolio investment (cross-border transactions and positions involving debt or equity securities, other than those included in direct investment or reserve assets), and other investment flows (a residual category that includes transactions other than those included in direct investment, portfolio investment, financial derivatives and employee stock options, and reserve assets). For detailed definition of each category, refer to Balance of Payments and International Investment Position Manual (IMF) at https://www.imf.org/external/pubs/ft/bop/2007/pdf/bpm6.pdf. The brief description provided in this footnote is from the same source.

${ }^{v}$ Adjusted for changes in reserves, capital transfers, and errors and omissions.

${ }^{\mathrm{vi}}$ It must be noted that push factors can be structural and cyclical as well. 